\title{
Ethnohistory
}

The Official Journal of the American Society for Ethnohistory

\section{A Special Issue Contents}

Ethnohistory and Africa The Undefining of Oral Tradition / David William 36:1 (Winter 1989) Cohen

Edward I. Steinhart, The Evolution of Ethnicity among the Acholi of special issue editor Uganda: The Precolonial Phase / Ronald R. Atkinson

West African Coastal Slavery in the Nineteenth Century: The Case of the Afro-European Slaveowners of Elmina / Larry W. Yarak

Eyewitness Accounts of Buganda History: The Memoirs of Ham Mukasa and His Generation John A. Rowe

The Structure of a Legacy: Military Slavery in Northeast Africa / Douglas H. Johnson

Recent articles The Ethnohistory of Events and Nonevents Raymond D. Fogelson

Ethnicity on the Maritime Peninsula, 1600-1759 Bruce J. Bourque

Social Organization by Decree in Colonial Highland Guatemala / Robert M. Hill II

"Very Serious Reflections": Inuit Dreams about Salvation and Loss in Eighteenth-Century Labrador Barnett Richling

Duke University Press Quarterly. Subscription prices: \$34 institutions, Journals Division $\$ 21$ individuals (includes membership 6697 College Station in the American Society for Ethnohistory). Durham, NC 27708 Single issue price: $\$ 8.50$ 
Ancient Mesoamerica will publish primarily in English, but will also feature contributions in Spanish. All papers will have Spanish (or English) summaries as a regular feature to enhance scholarly communication. When preparing your contribution, please remember that Ancient Mesoamerica unifies several different fields from archaeology to ethnohistory, art history and beyond. We also wish to reach nonspecialist readers. While some degree of technical language is often proper and necessary, jargon can always be avoided. Therefore, authors should strive for clear, lucid prose. The Editors will gladly discuss topics or contents of manuscripts prior to submission.

\section{Manuscript Submission}

Please submit 5 copies of the manuscript text and line drawings; colleagues with limited photocopying facilities may send only 1 copy. If photographs are included, only one set of original prints should be sent, along with 4 photocopies. Double-space the entire manuscript, including references and tables, with ample margins to permit editorial marking. The manuscript must be accompanied by a letter of transmittal stating that the work has not been published elsewhere, in whole or in part, nor is it under consideration for publication elsewhere. Papers may be submitted in Spanish or English. Artwork must be camera-ready and be securely packaged in a protective envelope. Mail manuscripts or make editorial inquiries to the Editorial Office (see inside cover for complete information).

\section{Peer Review Procedures}

Each contribution will be reviewed by at least three, and sometimes as many as five, outside readers who will make recommendations to the Editors concerning revision of the manuscript, acceptance or rejection. The reviewers' anonymous comments will be passed on to the authors.

\section{Categories of Papers}

(a) Full articles are longer contributions of general interest that are 25-30 double-spaced manuscript pages in length, including references; (b) reports are shorter contributions of about 15-20 pages in length focusing on important finds, reinterpretations, comments, and so on. The Editors or a Guest Editor will occasionally assemble a special section of related reports; and (c) notes are newsworthy items of a very short length.

\section{Editorial and Reference Style}

In general, follow American Antiquity style. Two abstracts of 150 words or less should be included: one in English and one in Spanish. Footnotes may be used, but only if deemed absolutely necessary; they should be numbered consecutively and collected at the end of the text. The order of manuscript ele- ments should be as follows: title page, abstracts pages, main text, Spanish summary, acknowledgments, footnotes, references, tables, and figures (line drawings and photographs in a protective envelope). Tables and figures should be numbered consecutively using Arabic numerals. Sample references:

Adams, Richard E. W.

1977 Prehistoric Mesoamerica. Little, Brown, Boston.

Clark, John E., and Thomas A. Lee, Jr.

1984 Formative Obsidian Exchange and the Emergence of Public Economies in Chiapas, Mexico. In Trade and Exchange in Early Mesoamerica, edited by Kenneth G. Hirth, pp. 100-105. University of New Mexico Press, Albuquerque.

Graham, Elizabeth

1987 Resource Diversity in Belize and Its Implications for Models of Lowland Trade. American Antiquity 52:753-767.

Love, Michael W.

1987 Olmec Interaction and the Formation of Social Inequality in Pacific Guatemala. Paper presented at the 86th Annual Meeting of the American Anthropological Association, Chicago.

Smith, Michael E.

1988 Long-Distance Trade under the Aztec Empire: The Archaeological Evidence. Unpublished manuscript on file, Department of Sociology and Anthropology, Loyola University of Chicago.

\section{Illustrations}

All figures must be camera-ready and be of professional quality. Please send oversize artwork for reduction to size or highcontrast photostats already reduced to exact size. Please allow for reduction when judging type size for captions. Put scales on the figures, not in legends.

\section{Electronic Input}

After a contribution is accepted, the Editors will ask the author to submit the article on a floppy disk, if possible. When doing so, please specify the type of computer used, the operating system, and program (e.g., IBM-PC, PC-DOS, WordPerfect). The electronic manuscript should be limited to standard ASCII characters, with two returns between all text elements, with two returns between each paragraph and reference, and with all lines beginning flush left. Omit formatting codes for indenting, centering, etc. If you do not use a word processor, your manuscript will be typeset in the traditional manner.

\section{Copyright and Offprints Policy}

Contributors must complete the Transfer of Copyright Agreement form, available from the Editors, before their paper can be transmitted for production. The lead author of each article or report will receive 25 free offprints from the Publisher, with the opportunity to purchase additional offprints and complete copies of the issue at favorable rates. 


\section{Ancient \\ Mesoamerica}

Volume 1, Number 1

Spring 1990

Editorial Remarks: A New Journal Based on an Old Idea

William R. Fowler, Jr.

1

Stephen D. Houston

\section{ARTICLES}

Big Man, Big Heart? A Mesoamerican View of the

Brian Hayden Emergence of Complex Society

Rob Gargett

Ancient Winds of Change: Climatic Settings and Prehistoric Social Complexity in Mesoamerica

Lewis C. Messenger, Jr.

The Study of Activities in Classic Households: Two Case Studies from Coba and Teotihuacan

Linda Manzanilla

Luis Barba

Maize Storage among the Puuc Maya: The Development

Michael P. Smyth

of an Archaeological Method

New Data on Sources of Obsidian Artifacts from Tikal, Guatemala

Household Archaeology at Cerén, El Salvador

Hattula Moholy-Nagy

Fred W. Nelson

Payson D. Sheets, Harriet F. Beaubien,

Marilyn Beaudry, Andrea Gerstle,

Brian McKee, C. Dan Miller,

Hartmut Spetzler, David B. Tucker

A Logograph in Maya Writing for the Verb "To Record"

Frederico Fahsen

SPECIAL SECTION: RETHINKING MIXTEC CODICES Introduction

William R. Fowler, Jr.

The Search for History in Mixtec Codices

Stephen D. Houston

Maarten Jansen

Mixtec Landscape Perception and Archaeological

John M. D. Pohl

Settlement Patterns

Bruce E. Byland

John Monaghan

133

Poetics and Metaphor in Mixtec Writing

Mark B. King 